DOI: $10.25264 / 2415-7384-2017-5-158-169$

УДК 159.942.2

\title{
М. М. Стасюк
}

\section{ТЕОРЕТИЧНИЙ АНАЛІЗ ВПЛИВУ ЕМОЦІЙНОГО ІНТЕЛЕКТУ НА ПРОЦЕС СОЦАЛЬНОЇ АДАПТАЦЇ̈}

У статті розглянуто основні підходи до визначення поняття «емоційний інтелект»; його структури; зовнішній (міжособистісний) і внутрішній (внутрішньоособистісний) вектори спрямованості. Проаналізовано основні моделі та способи вимірювання емоиійного інтелекту. Описано компоненти емоційного інтелекту, які можуть слугувати основою для успішної соиіально-психологічної адаптації: темперамент, особливості переробки інформації, впевненість у своїй емоційній компетентності, емоційні знання та навички.

Ключові слова: емоиійний інтелект, моделі емоиійного інтелекту, психологічна адаптація, адаптивність, копінг-стратегії.

В статье рассмотрены основные подходы к определению понятия «эмоциональный интеллект»; его структуры; внешний (межличностный) и внутренний (внутриличностный) векторы направленности. Проанализированы основные модели и способы измерения эмоционального интеллекта. Описаны компоненты эмоционального интеллекта, которые могут служить основой для успешной сочиально-психологической адаптации: темперамент, особенности переработки информачии, уверенность в своей эмочиональной компетентности, эмочиональные знания и навыки.

Ключевые слова: эмоциональный интеллект, модели эмоционального интеллекта, психологическая адаптация, адаптивность, копинг-стратегии.

The article considers basic approaches to the definition of the concept of emotional intelligence; its structures; external (interpersonal) and internal (intrapersonal) direction vectors. The basic models and methods of measurement emotional intelligence have been analysed. The article describes the components of emotional intelligence that can form grounds for successful socio-psychological adaptation: 
temperament, peculiarities of information processing, confidence in person's own emotional competence, emotional knowledge and skills.

Key words: emotional intelligence, models of emotional intelligence, psychological adaptation, adaptability, coping strategies.

Постановка проблеми. Теорія психологічної адаптації розвивається в руслі різних психологічних підходів і напрямів. На сьогодні не існує єдиної думки про зміст цього поняття. Спроби дослідників пов' язати здатність до успішної адаптації (адаптивність) 3 рівнем інтелекту (IQ) не увінчалися успіхом. Показник IQ не дозволяє хоча б приблизно передбачити потенціал людини в соціальному житті. Тому дослідники звернулися до поняття «емоційний інтелект» (EQ). Водночас думки вчених щодо взаємозв'язку емоційного інтелекту та соціальної адаптації часто не збігаються або $є$ прямо протилежними. Одні (Р. Бар-Он, К. Брез) стверджують, що соціальна адаптація прямо пропорційно залежить від емоційного інтелекту; інші (Д. Люсін, М. Зайднер та ін.) пропонують розглядати емоційний інтелект результатом соціальної адаптації.

Нині зв'язок емоційного інтелекту та соціальної адаптації є обгрунтованим, проте незрозумілими залишаються природа цього зв'язку та причинно-наслідковість.

Аналіз останніх досліджень і публікацій. На сучасному етапі вивчення емоційний інтелект цікавить дослідників із погляду можливості практичного застосування: в організаційній психології для добору ефективності управлінського персоналу (М. Зайднер, Р. Річард, Дж. Метьюз), успішності керівників високої ланки (Д. Гоулдмен); в педагогічній психології питання впливу емоційного інтелекту на академічну успішність (Е. Аронсон), зниження антисоціальної поведінки (М. Гріндберг), формування психологічного клімату у класі (Р. Вайсберг); у психології лідерства (Р. Купер, В. Сааф).

Окремої уваги заслуговують дослідження ролі емоційного інтелекту у процесі адаптації: зв'язок емоційного інтелекту та копінг-стратегій (Р. Бар-Он), стресозахисну та адаптаційну функції емоційного інтелекту (Є. Носенко, Н. Коврига), адаптивні риси особистості та їхній зв'язок із емоційним інтелектом (Дж. Метьюз), соціально-психологічна адаптація в різних сферах, наприклад, студентське середовище (С. Дерев'янко), професійне становлення (В. Зарицька, Ю. Бреус) тощо. 
Мета роботи - розглянути сучасні погляди на структуру і вимірювання емоційного інтелекту; висвітлити значення емоційного інтелекту чи окремих його елементів у процесі адаптації.

Виклад основного матеріалу. Ідея виділення емоційного інтелекту виникла із поняття «соціальний інтелект», яке розробляли Е. Торндайк, Дж. Гилфорд, Г. Айзенк [2; 10]. Поняття якраз і стало ланкою, що пов'язала афективну і когнітивну складові процесу пізнання. У сфері соціального інтелекту сформувався підхід, що розглядав пізнання людини не як «апарат для рахування», а як когнітивно-емоційний процес.

Один із представників гуманістичної хвилі Пітер Салоуей у 1990 році випустив статтю під назвою «Емоційний інтелект», яка стала першою публікацією про емоційний інтелект. Він писав, що останні декілька десятків років уявлення і про інтелект, і про емоції докорінно змінилися. Розум перестали сприймати як ідеальну субстанцію, емоції як головний ворог інтелекту, й обидва явища набули реального значення в повсякденному людському житті [17].

На сучасному етапі досліджень існує декілька моделей емоційного інтелекту. Перша модель була розроблена авторами цього терміну Пітером Салоуеєм і Джоном Мейєром [17]. На

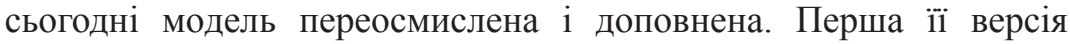
3'явилася в 1990 році. Автори визначали емоційний інтелект як «здібність відстежувати власні і чужі почуття й емоції, розрізняти їх, використовувати цю інформацію для спрямування мислення і дій» [17]. У сучасному вигляді модель емоційного інтелекту $є$ складним конструктом, який складається із здібностей, що поділені на чотири компоненти «гілки». Кожен компонент має два вектори направленості: щодо своїх емоцій і щодо емоцій інших людей. Структура емоційного інтелекту ієрархічна i відповідає тому, як формуються у процесі індивідуального розвитку ці компоненти: 1) розрізнення, сприйняття та вираження емоцій; 2) емоційна фасилітація мислення; 3) розуміння емоцій; 4) управління емоціями.

На думку Д. Гоулмена, емоційний інтелект - це здатність усвідомлювати власні почуття, почуття інших людей, мотивувати самого себе та інших, управляти емоціями як наодинці з самим собою, так і щодо інших. Дослідник узяв за основу своєї моделі емоційного інтелекту первинну модель Салоуея і Мейєра, 
об’єднавши когнітивні здібності (із попередньої моделі) та особистісні характеристики: ентузіазм, наполегливість і соціальні навики. Саме так модель намагається побудувати взаємозв'язки між емоційною, когнітивною сферами та особистісними характеристиками $[13 ; 15]$.

Модель Р. Бар-Она описує поняття «емоційний інтелект» ще ширше: «Всі не когнітивні здібності, знання і компетентність, які дають можливість людині успішно справлятися з різноманітними життєвими ситуаціями» $[11 ; 16]$. Так, автор розглядає емоційний інтелект як конструкт, що об’єднує адаптаційні здібності, перегукується із «долаючими» стратегіями (копінг). У структурі емоційного інтелекту Р. Бар-Он виділив п'ять сфер компетентності, котрі ідентифікуються із п'ятьма компонентами емоційного інтелекту, кожен із яких складається із субкомпонентів: 1) пізнання себе: усвідомлення своїх емоцій, упевненість у собі, самоповага, самоактуалізація, незалежність; 2) навики міжособистісного спілкування: емпатія, міжособистісні взаємовідносини, соціальна відповідальність; 3) здатність до адаптації: вирішення проблем, зв'язок із реальністю, гнучкість; 4) управління стресовими ситуаціями: стійкість до стресу, контроль за імпульсивністю; 5) переважний настрій: щастя, оптимізм. Описана модель характеризує емоційний інтелект як особистісну рису. Р. Бар-Он розробив методику для дослідження емоційного інтелекту, яка має назву EQ-i. Проте варто зазначити, що методику створювали і розробили на основі теоретичних аналізів і вона не містить у собі емпіричного підгрунтя [16].

Російський дослідник Д. Люсин запропонував свою модель емоційного інтелекту. Автор визначає поняття «емоційний інтелект» як «здатність до розуміння своїх і чужих емоцій і управління ними» [11]. Так, Д. Люсин пропонує розглядати емоційний інтелект, як явище, що має подвійну природу: з одного боку, когнітивну (здатність розпізнати емоцію, ідентифікувати іiі і дати їй вербальну оцінку, здатність розуміти та усвідомлювати процес формування і розвитку емоції, причинно-наслідкові зв'язки), а 3 другого - особистісну (спрямованість особистості на емоційну сферу, увага до внутрішнього світу як свого, так і інших людей, здатність переживати емоцію і водночас контролювати їі зовнішнє вираження). У цій моделі також розглядають два різновиди емоційного інтелекту: внутрішній (внутрішньоособистісний, здат- 
ність розуміти й управляти власними емоціями); зовнішній (міжособистісний, здатність розпізнавати, ідентифікувати та управляти емоціями інших людей).

Згідно з ідеєю автора емоційний інтелект - це не вроджена здібність, а швидше психологічне утворення, яке формується у процесі життя людини на основі когнітивних здібностей та особливостей емоційності під впливом уявлень про емоції. Останній пункт (уявлення про емоції), який містить обізнаність із позитивного погляду про важливість і цінність емоційної сфери як джерела інформації про себе і про інших людей, значимий тим, що відкриває шляхи для розвитку емоційного інтелекту.

Моделі емоційного інтелекту різноманітні, грунтуються на різних основах і баченнях певного психологічного конструкту. До першого типу можна віднести моделі, які трактують емоційний інтелект як здібність, до другого - як рису [11]. Таким чином, науковий статус поняття «емоційний інтелект» поки недостатньо високий у зв'язку з тим, що результати опитувальників і тестів емоційного інтелекту низько корелюють один із одним; це викликає питання щодо наукової спроможності цих двох підходів.

Термін «адаптація» запозичений у психологію з природничих наук, зокрема, біології. На сучасному етапі розвитку психології поняття «адаптація» $є$ добре теоретично розробленим і слугує основою для введення більш специфічних категорій «соціалізація», «регуляція», «саморегуляція», «інтеграція» тощо. У такому контексті адаптація відображає процес і результат пристосування до умов навколишнього середовища в найширшому значенні цього поняття. Важливо зазначити, що поняття описує і стан (як константу в сучасних умовах, у теперішній момент часу) і процес (як послідовність етапів). Але окремо аналіз процесу адаптації водночас часто не пропонують і не здійснюють (А. Бек, С. Джудит, Ф. Зимбордо, М. Лейпе та ін.) $[1 ; 5 ; 14]$.

Психіка людини функціонує на загально біологічних засадах, тому підтримка «гомеостазу» на психічному і психологічному рівні також $є$ одним із завдань організму. Водночас людина $є$ істотою соціальною, тобто такою, яка має потребу в соціальному оточенні. Таким чином, психологічну складову процесу адаптації можна описувати як соціально-психологічну. Цей термін описує психічне життя, яке містить внутрішньоособистісні та міжособистісні процеси. 3 позицій системного підходу успішність і адекватність 
процесу адаптації залежить як від індивідуально-психологічних особливостей, так і від чинників середовища (Г. Балл, Н. Завацька, Г. Ложкін, М. Макаренко, А. Налчаджян, А. Реан, Т. Яценко, Н. Жигайло) [5; 12].

Загальноприйнятим є твердження, що процес адаптації базується на індивідуальних особливостях особистості. Кожна із теорій особистості згідно зі своїми поглядами на структуру особистості описує роль і місце адаптаційних процесів у розвитку і функціонуванні особистості [5; 7]. Проте сам процес адаптації і чинники, які на нього впливають, кожна з теорій позиціонує по-різному. Загалом у поглядах на адаптація теорії можна поділити на дві групи: теорії, які не містять емоційний інтелект та/або окремі його складові в системі адаптації, і теорії, які розглядають емоційний інтелект, як значимий конструкт для адаптації [6].

Показниками успішної соціально-психологічної адаптації є відповідний соціальний статус індивіда в певному середовищі, а також психологічна задоволеність собою, середовищем, окремими деталями та затраченим на це ресурсом. Низька соціально-психологічна адаптація - це відсутність власного місця в середовищі, певної ролі, або невдоволеність середовищем і собою в ньому. Результативність адаптації залежить від особливостей середовища й індивіда. Чим складніше нове середовище (наприклад, більше соціальних зв'язків, складніше спільна діяльність, вище соціальна неоднорідність), тим є важчою для індивіда соціально-психологічна адаптація. Найскладніше середовище - те, у якому постійно відбуваються зміни.

Л. Албегова поряд із адаптацією до зовнішніх умов виділяє внутрішню адаптацію, тобто таку, яка сфокусована на внутрішньоособистісних процесах [12]. Автор сформулювала кілька видів внутрішньої адаптації: 1) внутрішня адаптація, спрямована на вирішення внутрішніх конфліктів й інших внутрішньопсихічних проблем особи; 2) внутрішня структурна адаптація у вузькому сенсі це процес координування якого-небудь адаптивного механізму; 3) внутрішня структурна адаптація в широкому сенсі: пристосування адаптивного механізму або адаптивного комплексу до всієї структури особи [14].

Такий вид адаптації повинен, як ніякий інший, містити емоційну складову. Проте цей аспект поки залишається недослідженим. 
Значення емоційного інтелекту для адаптації є актуальним для багатьох наукових шкіл $[12 ; 13 ; 16]$. Озвучено багато теорій, які пояснюють, як повинен емоційний інтелект впливати на успішність адаптації. Наприклад, К. Брез говорить, що люди з високим рівнем емоційного інтелекту більш ефективно поводять себе в ситуації агресивної провокації. Люди з низьким рівнем емоційного інтелекту досить ворожо ставляться до навколишнього світу, нечасто погоджуються на компроміси. Група досліджуваних із низьким рівнем емоційного інтелекту володіє досить високим рівнем агресивності.

Із другого боку, не зрозуміло як уміння на фото розпізнати емоцію дозволяє вибудовувати ефективні соціальні зв'язки. Дослідження, які проводили до сьогодні, не дають відповіді для розуміння цього процесу.

Одним із важливих компонентів адаптації, які зараз активно вивчають $є$ подолання (копінг-стратегіi). Психологічне призначення подолання як одного із видів саморегуляції полягає в тому, щоб якомога краще адаптувати людину до вимог ситуації шляхом оволодіння, послаблення чи пом'якшення цих вимог. За словами С. Нартової-Бочавер [12], поняття «подолання» охоплює широкий спектр людської активності, враховуючи в загальному вигляді всі види взаємодії суб'єкта з внутрішніми і зовнішніми завданнями.

Підхід Р. Бар-Она грунтується на ідеї, що емоційний інтелект повинен сприяти адаптації людини до реального життя. Справді, в дослідженнях показано, що його опитувальник EQ-i позитивно корелює 3 пристосованістю, суб' єктивним благополуччям і соціальним успіхом. Високі бали EQ-i пов'язані із найбільш адаптивними копінг-стратегіями, які направлені на проблему. Однак результати цих досліджень порушують інші питання. Наприклад, наявність негативної кореляції між EQ-і і шкалою, яка оцінює вираженість психопатологічних симптомів може свідчити про те, що EQ-i вимірює не стільки здатність, що дозволяє долати життєві труднощі, скільки наслідки зустрічей із цими життєвими труднощами [16].

Як було сказано вище, копінг-стратегії $є$ по-різному ефективними, що залежить і від ситуації. Зазвичай стратегії, спрямовані на проблему, і справді є більш ефективними, ніж стратегії, сфокусовані на емоціях. Проте з цього правила є багато винятків. Немає достовірних даних, котрі б емпірично підтвердили ефективність 
однієї стратегії порівняно з іншою. Всі висновки базуються на якісних описах.

Дж. Метьюз, Р. Зайднер, Д. Люсин запропонували на основі аналізу різних моделей емоційного інтелекту зведену схему, яка розглядає структури емоційного інтелекту у зв'язку з їх значенням для адаптації. У таблиці 1 представлено групи конструктів та їх характеристики: методи вимірювання (у форматі емоційного інтелекту та можливі аналогії під час вимірювання психометричного інтелекту), розвиток в онтогенезі та значення для адаптації.

Темперамент. Характеристики темпераменту дитини (наприклад, переважання негативних афектів) багато в чому визначають такі вимірювання особистості дорослого, як нейротизм, екстраверсія й усвідомленість. Дж. Метьюз із співавторами [19] на основі проведених досліджень стверджують, що ці риси високо корелюють 3 опитуваннями на емоційний інтелект. В основі цих особистісних рис лежить комплекс біологічних і когнітивних процесів, адаптивна функція яких залишається не цілком зрозумілою, оскільки має складний, багатоаспектний характер. Д. Люсин приводить приклад із дитиною, схильною до дистресу. У неї можуть виникати труднощі у взаємодії з дорослим, але водночас іiї чутливість до дистресу може привертати увагу дорослого і допомагати дитині уникати небезпечних ситуацій [11].

Опрацювання інформації. Можна припустити, що існують деякі когнітивні чинники, що сприяють переробці емоційно забарвлених стимулів, а значить впливають на рівень емоційного інтелекту. Мабуть, як інструмент для їх вимірювання можна розглядати, зокрема, емоційний тест Струпа і методику Шерера на розпізнавання емоційного забарвлення голосів. Значення цих факторів для адаптації ще належить з'ясувати. Наприклад, незрозуміло, чи вигідна для організму швидка переробка позитивних стимулів і повільна переробка негативних стимулів.

Упевненість у своїй емоційній компетентності. Цей аспект емоційного інтелекту відображає знання й уявлення людини про свої можливості розуміти емоції, керувати ними і використовувати в міжособистісній взаємодії. В основі впевненості у своїй емоційній компетентності лежать процеси самооцінки і саморегуляції. Таким чином, цей конструкт формується у процесі соціального научіння [22]. 


\section{Фундаментальні основи емоційного інтелекту}

в контексті їх значення для адаптації

\begin{tabular}{|c|c|c|c|c|c|}
\hline $\begin{array}{l}\text { Кон- } \\
\text { структ }\end{array}$ & $\begin{array}{l}\text { Можливі } \\
\text { методики } \\
\text { для } \\
\text { вимірю- } \\
\text { вання } \\
\end{array}$ & $\begin{array}{l}\text { Еквіваленти } \\
\text { в досліджен- } \\
\text { нях психо- } \\
\text { метричного } \\
\text { інтелекту }\end{array}$ & $\begin{array}{l}\text { Процеси, } \\
\text { які лежать в } \\
\text { основі кон- } \\
\text { структу }\end{array}$ & $\begin{array}{l}\text { Як виникає } \\
\text { в онтоге- } \\
\text { незі }\end{array}$ & $\begin{array}{l}\text { Значення } \\
\text { для адап- } \\
\text { тації }\end{array}$ \\
\hline $\begin{array}{l}\text { Темпера- } \\
\text { мент }\end{array}$ & $\begin{array}{l}\text { Опиту- } \\
\text { вальники, } \\
\text { що ви- } \\
\text { мірюють } \\
\text { фактори } \\
\text { «Великої } \\
\text { п’ятірки»; } \\
\text { EQ-і }\end{array}$ & Немає & $\begin{array}{l}\text { Нейронні і } \\
\text { когнітивні } \\
\text { процеси, } \\
\text { управління } \\
\text { збуджен- } \\
\text { ням, } \\
\text { увагою і } \\
\text { підкріплен- } \\
\text { ням }\end{array}$ & $\begin{array}{l}\text { Вродже- } \\
\text { ний і } \\
\text { формуєть- } \\
\text { ся } \\
\text { на ранніх } \\
\text { стадіях } \\
\text { розвитку }\end{array}$ & $\begin{array}{l}\text { Змішане: } \\
\text { виділені } \\
\text { фактори } \\
\text { можуть мати } \\
\text { і позитивне, } \\
\text { і негативне } \\
\text { значення }\end{array}$ \\
\hline $\begin{array}{l}\text { Опра- } \\
\text { цювання } \\
\text { інформа- } \\
\text { ції }\end{array}$ & $\begin{array}{l}\text { Емоцій- } \\
\text { ний тест } \\
\text { Струпа, } \\
\text { методика } \\
\text { Шерера на } \\
\text { розпіз- } \\
\text { навання } \\
\text { емоційного } \\
\text { забарвлен- } \\
\text { ня голосу }\end{array}$ & $\begin{array}{l}\text { Час реакції } \\
\text { вибору, } \\
\text { робоча } \\
\text { пам’ять }\end{array}$ & $\begin{array}{l}\text { Робота } \\
\text { окремих } \\
\text { модулів } \\
\text { системи } \\
\text { переробки } \\
\text { інформації }\end{array}$ & $\begin{array}{l}\text { Вроджений } \\
\text { і форму- } \\
\text { ється на } \\
\text { ранніх } \\
\text { стадіях } \\
\text { розвитку }\end{array}$ & $\begin{array}{l}\text { Не визначе- } \\
\text { но: незро- } \\
\text { зуміло, чи } \\
\text { необхідна } \\
\text { швидкість } \\
\text { переробки } \\
\text { інформації } \\
\text { для адап- } \\
\text { тації }\end{array}$ \\
\hline $\begin{array}{l}\text { Впев- } \\
\text { неність } \\
\text { у своїй } \\
\text { емо- } \\
\text { ційній } \\
\text { компе- } \\
\text { тентності }\end{array}$ & $\begin{array}{l}\text { Окремі } \\
\text { субком- } \\
\text { поненти } \\
\text { SSRI; } \\
\text { TEIQue; } \\
\text { ЭмИн }\end{array}$ & $\begin{array}{l}\text { Самооцінки } \\
\text { інтелекту }\end{array}$ & $\begin{array}{l}\text { Самооцінка, } \\
\text { саморегу- } \\
\text { ляція }\end{array}$ & $\begin{array}{l}\text { Научіння і } \\
\text { соціаліза- } \\
\text { ція }\end{array}$ & $\begin{array}{l}\text { Переважно } \\
\text { позитивне }\end{array}$ \\
\hline $\begin{array}{l}\text { Емоційні } \\
\text { знання і } \\
\text { навики }\end{array}$ & MSCEIT & $\begin{array}{l}\text { Кристалі- } \\
\text { зований } \\
\text { інтелект і } \\
\text { декларатив- } \\
\text { ні знання }\end{array}$ & $\begin{array}{l}\text { Набуті про- } \\
\text { цедурні та } \\
\text { декларатив- } \\
\text { ні навички }\end{array}$ & $\begin{array}{l}\text { Научіння, } \\
\text { соціалі- } \\
\text { зація і } \\
\text { формуван- } \\
\text { ня окремих } \\
\text { навичок і } \\
\text { знань } \\
\end{array}$ & $\begin{array}{l}\text { Переважно } \\
\text { позитивне; } \\
\text { але в деяких } \\
\text { контекстах } \\
\text { може бути } \\
\text { негативним }\end{array}$ \\
\hline
\end{tabular}

Тому він більше повинен залежати від навчання на різних етапах онтогенезу, ніж від темпераменту. Висока впевненість у своїй 
емоційній компетентності здебільшого відіграє позитивну роль в адаптації. Водночас дослідники стверджують, що може бути i негативний вплив на адаптацію, якщо самооцінка неадекватна i схильна до нарцисичної [18; 19].

Емоційні знання і навички. Високий емоційний інтелект передбачає наявність конкретних знань і навичок, що допомагають успішно вести себе в певних ситуаціях. Д. Люсин разом із співавторами припускають, що навички такого виду аналогічні когнітивним. Набуття та реалізація навичок у галузі емоцій полегшуються в разі високої впевненості у своїй емоційній компетентності. Очевидно, що емоційні знання і навички відіграють позитивну роль в адаптації, однак необхідно, щоб вони відповідали контексту і гнучко змінювалися залежно від ситуації.

Ще один момент - це прояв емоційного інтелекту залежно від середовища. В умовах дослідження, які зазвичай $є$ спокійними, $\epsilon$ більше можливостей зосередитися на завданні, на емоційних проявах, інші умови можуть сприяти пригніченню емоційного інтелекту. Якщо це правильне припущення, то емоційний інтелект - це характеристика, яка описує процес і результат діяльності людини в певних умовах середовища з урахуванням своїх особистісних характеристик.

Висновки та перспективи подальших досліджень. Аналізуючи проблему емоційного інтелекту в сучасних психологічних дослідженнях, можна зробити висновок, що науковий статус поняття «емоційний інтелект» поки недостатньо високий у зв'язку з тим, що існує дві альтернативні моделі, на яких грунтується його вимірювання. Важливо відзначити, що результати опитувальників і тестів емоційного інтелекту низько корелюють один з одним; це викликає питання щодо наукової спроможності цих двох підходів.

Подальші перспективи досліджень полягають у тому, щоб пояснити, як пов'язані індивідуальні відмінності емоційного інтелекту з адаптацією. Окремої уваги заслуговує дослідження причиннонаслідкових зв'язків емоційного інтелекту та адаптації, оскільки на сьогодні в літературі існує два протилежних підходи. Один із них свідчить про можливості емоційного інтелекту для розвитку адаптивності, другий - про те, що емоційний інтелект $є$ продуктом успішної адаптації.

Перспективним може бути дослідження суперечностей, які виникають у дослідженнях зв'язків емоційного інтелекту та ко- 
пінг-стратегій про те, що люди з високим рівнем емоційного інтелекту не звертають увагу на емоційну складову у стресовій ситуації, тоді як у спокійному стані вони досить чутливі до емоцій, здатні їх відчувати, розпізнавати та ідентифікувати.

\section{Література:}

1. Абабков В. Адаптация к стрессу. Основы теории, диагностики, терапии / В. Абабков, М. Перре. - СПб. : Речь, 2004. - 166 с.

2. Айзенк Г. Ю. Интеллект: новый взгляд / Г. Ю. Айзенк // Вопросы психологии. - 1995. - № 1. - С. 111-131.

3. Андреева И. Н. Понятие и структура эмоционального интеллекта / И. Н. Андреева // Социально-психологические проблемы ментальности: 6-я Международная научно-практическая конференция. - Смоленск : СГПУ, 2004. - Ч. 1. - С. 22-26.

4. Белоконь О. В. Эмоциональный интеллект и феномен лидерства: эксперимент «Строим вместе» практике / О. В. Белоконь // Психология. Журнал высшей школы экономики - 2008. - Т. 5. № 3. - C. 137-144.

5. Боярин Л. В. Теоретичний аналіз вивчення проблеми соціальної адаптації в психологічній літературі / Л. В. Боярин // Теоретичні і прикладні проблеми психології - 2013. - № 3(32). - С. 55-61.

6. Деревянко С. П. Адаптивные характеристики эмоционального интеллекта / С. П. Деревянко // Психология и современное общество: взаимодействие как путь взаиморазвития : материалы междунар. науч.-практ. конф., 13-14 апр. 2007 г. / Санкт-Петербургский институт управления и права. - СПб. : СПбИУиП, 2007. - Ч. 1. C. $103-105$.

7. Дерев'янко С. П. Роль емоційного інтелекту в соціально-психологічній адаптації особистості / С. П. Дерев'янко // Biсник Чернігівського державного педагогічного університету імені Т. Г. Шевченка. Серія: Психологічні науки : [зб. наук. праць у 2-х т.]. Чернігів : ЧДПУ, 2008. - Вип. 59 - Т. 1. - С. 94-98.

8. Жигайло Н. Особливості соціальної адаптації студентів-першокурсників / Н. Жигайло // Наукові записки Інституту психології імені Г. С. Костюка АПН України / [зб. наук. праць / наук. ред. Максименко С. Д.]. - К. : Главник, 2005. - Вип. 26. - Т. 4. - С. 65-70.

9. Жигайло Н. І. Роль емоційного інтелекту в процесі професійної освіти / Н. І. Жигайло, М. М. Стасюк // Педагогіка і психологія професійної освіти. - 2016. - № 4. - С. 87-97.

10. Люсин Д. В. Современные представления об эмоциональном интеллекте / Д. В. Люсин // Социальный интеллект: теория, измерение, 
исследования ; Под ред. Д. В. Люсина, Д. В. Ушакова. - М. : Изд-во «Институт психологии РАН», 2004. - С. 29-36.

11. Робертс Р. Д. Эмоциональный интеллект: проблемы теории, измерения и применения на практике / Р. Д. Робертс, Д. Мэттьюс, М. Зайднер, Д. В. Люсин // Психология. Журнал высшей школы экономики. - 2004. - Т. 1. - № 4. - С. 3-26.

12. Ромм М. В. Философия и психология адаптивных процессов: учеб.пособие для студ. высш. учеб. заведений / М. В. Ромм. - М. : Издательство Московского психолого-социального института; - Воронеж : Издательство НПО «МОДЭК», 2006. - 296 с.

13. Стернберг Р. Дж. Практический интеллект / Р. Дж. Стернберг и др. - СПб. : Питер, 2002. - 272 с.

14. Ткачишина О. Р. Соціально-психологічна адаптація особистості як невід'ємна складова іiі соціалізації / О. Р. Ткачишина // Проблеми загальної та педагогічної психології : зб. наук. праць Ін-ту психології ім. Г. С. Костюка АПН України. - К., 2006. - Т. VIII. Вип. 1. - С. 341-348.

15. Штроо В. А. Эмоциональный интеллект участников как фактор эффективности деловых переговоров [Электронный ресурс] / В. А. Штроо, С. Ю. Серов // Организационная психология. 2011. T. 1. - № 1. - С. 8-23. - Режим доступа : http://orgpsyjournal.hse.ru.

16. Bar-On R. Emotional and social intelligence: Insights from the Emotional Quotient Inventory / R. Bar-On, J. D. A. Parker (eds.) // Handbook of emotional intelligence. - San Francisco : Jossey-Bass, 2000. - P. 363-388.

17. MacCann C., Matthews G., Zeidner M., Roberts R. D. Psychological assessment of emotional intelligence: a review of self-report and performancebased testing // International Journal of Organizational Assessment. 2003. - P. 247-274.

18. Matthews G., Roberts R. D., Zeidner M. Seven myths about emotional intelligence // Psychological Inquiry. 2004. - P. 179-196.

19. Matthews G., Zeidner M., Roberts R.D. Emotional intelligence : Science and myth. - Cambridge, MA: MIT Press, 2003. 